\title{
Publisher Correction: Development of a genetically encodable FRET system using fluorescent RNA aptamers
}

\author{
Mette D.E. Jepsen (10 1, Steffen M. Sparvath (10) 1, Thorbjørn B. Nielsen (10 1,2, Ane H. Langvad (1) 1,3, Guido Grossi (1) 1,
} Kurt V. Gothelf ${ }^{1,2} \&$ Ebbe S. Andersen (1) ${ }^{1,3}$

Correction to: Nature Communications https://doi.org/10.1038/s41467-017-02435-x, published online 02 January 2018

In the original version of this Article the last section of the Methods describing Fluorescence microscopy was inadvertently omitted during the production process. This has now been corrected in the PDF and HTML versions of the Article.

Published online: 09 February 2018

\begin{abstract}
(c) (i) Open Access This article is licensed under a Creative Commons Attribution 4.0 International License, which permits use, sharing, adaptation, distribution and reproduction in any medium or format, as long as you give appropriate credit to the original author(s) and the source, provide a link to the Creative Commons license, and indicate if changes were made. The images or other third party material in this article are included in the article's Creative Commons license, unless indicated otherwise in a credit line to the material. If material is not included in the article's Creative Commons license and your intended use is not permitted by statutory regulation or exceeds the permitted use, you will need to obtain permission directly from the copyright holder. To view a copy of this license, visit http://creativecommons.org/licenses/by/4.0/.
\end{abstract}

(C) The Author(s) 2018

\footnotetext{
${ }^{1}$ Interdisciplinary Nanoscience Center, Aarhus University, 8000 Aarhus C, Denmark. ${ }^{2}$ Department of Chemistry, Aarhus University, 8000 Aarhus C, Denmark. ${ }^{3}$ Department of Molecular Biology and Genetics, Aarhus University, 8000 Aarhus C, Denmark. Mette D.E. Jepsen and Steffen M. Sparvath contributed equally to this work. Correspondence and requests for materials should be addressed to E.S.A. (email: esa@inano.au.dk)
} 